\title{
Development and Validation of RP-HPLC Method for the Estimation of Voriconazole in Bulk and Pharmaceutical Dosage Form
}

\author{
SREERAMAMURTHY PYLA*1 ${ }^{*}$ K. SRINIVAS ${ }^{2}$, JOGENDRAKUMAR YVV ${ }^{1}$, \\ JAGADEESH PANDA $^{1}$ and P. SANDHYA ROSE ${ }^{1}$
}

${ }^{1}$ Raghu College of Pharmacy, Dakamarri (V), Bheemili (M), Visakhapatnam Dist. A.P, India

${ }^{2}$ Sri Vasavi Institute of Pharmaceutical Sciences, T. P. Gudem, E. G District, A.P, India srirampyla@gmail.com

Received 31 May 2014 / Accepted 29 June 2014

\begin{abstract}
A simple, accurate and precise reverse phase HPLC method was developed for the estimation of Voriconazole in bulk and pharmaceutical dosage form. The drug was resolved on an enable C18G column ( $250 \mathrm{~mm} \times 4.6 \mathrm{~mm}$ i.d, $5 \mu \mathrm{m}$ particle size) used with photodiode array UVVisible detector using the mobile phase consisting of Acetonitrile and water in the ratio of 60:40V/V. The flow rate was $1 \mathrm{~mL} / \mathrm{min}$ and the effluent was monitored at $256 \mathrm{~nm}$. The retention time of the drug was $5.360 \mathrm{~min}$. The linearity of the drug was found to be the concentration range $10-50 \mu \mathrm{g} / \mathrm{mL}$. The method was found to be reproducible with relative standard deviation of $<2 \%$. The percentage recovery was $99.89-100.86 \%$. The results of method have been validated according to ICH guidelines requirements. This method can be successfully employed for the quantitative analysis of Voriconazole in bulk and pharmaceutical dosage form.
\end{abstract}

Keywords: Voriconazole, Reverse phase HPLC, Method development, UV-Visible detector

\section{Introduction}

Voriconazole, chemically is ( $\alpha R, \beta S)$-(2,4-difluorophenyl)-5-fluoro- $\beta$-methyl- $\alpha$-( $1 H$-1.2.4triazol-1-yl-methyl)-4-pyrimideethanol (Figure 1). It is a second generation broad spectrum triazole introduced to treat fungal infections like invasive aspergillosis, disseminated infections caused by fluconazole resistant candida, fusarium infections and febrile neutropenia not responding to antibacterial therapy ${ }^{1}$ and its primary mode of action is by inhibition of the fungal cytochrome $\mathrm{P}_{450}$ dependent $14 \alpha$-steroldimethylase, an essential enzyme in ergosterol biosynthesis ${ }^{2}$.

Literature survey revealed that a few analytical methods have been reported for the quantitative estimation of voriconazole in pharmaceutical dosage form and in biological fluids. A RP-HPLC method for simultaneous determination of the azoles and its metabolite hydroxy-itra-conazole in human plasma with UV detection is reported in the literature ${ }^{3}$. Direct 
injection HPLC method for the determination of voriconazole in plasma using internal surface reversed-phase column was studied by Pehourcq et al. ${ }^{4}$. Determination of voriconazole in aqueous humor by liquid chromatography- electrospray ionization- mass spectrometry also reported ${ }^{5}$. An efficient HPLC method for quantification of voriconazole in plasma and microdialysate reflecting an important target site was studied by Franziska Simmel et $a l .{ }^{6}$. RP-HPLC method for determination of voriconazole in bulk and cream formulation was reported by Manali W. Jain et al. ${ }^{7}$. Development and validation of stability indicating RP-HPLC method for voriconazole was studied by Khetre et al. ${ }^{8}$. A validated LC method for separation and quantification of voriconazole and its enantiomer is also available in the literature ${ }^{9}$. HPLC method for quantitative determination of voriconazole in rat and Beagle dog plasma was reported by Shan cheng et al. ${ }^{10}$.

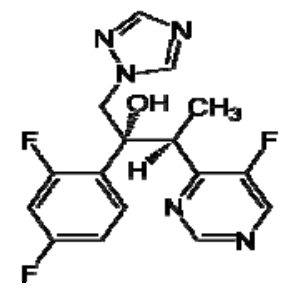

\section{Experimental}

Figure 1. Structure of Voriconazole

Voriconazole of pharmaceutical grade were kindly supplied by Alkem laboratories Ltd, Mumbai, India. Acetonitrile and water of HPLC grade were purchased from Merck, Mumbai, India. High purity deionized water was obtained by double distillation and purification through milli-Q water purification system. The $0.45 \mu \mathrm{m}$ membrane filter was purchased from Advanced Microdevice Pvt Ltd., Chandigarh. The tablet formulation (VFEND, Pfizer Ltd.) containing $50 \mathrm{mg}$ of voriconazole was procured from local market and used for analysis of marketed formulation.

The liquid chromatographic system was a Binary Shimadzu prominence HPLC System in gradient mode with a $20 \mu \mathrm{L}$ sample injection loop (manual) and SPD 20A Photo diode array UV-Visible detector. The output signal was monitored and integrated using LC solutions software on an enable C18G column ( $250 \mathrm{~mm} \times 4.6 \mathrm{~mm}$ i.d, $5 \mu \mathrm{m}$ particle size). In addition, an Analytical balance (Shimadzu uniblock ATX 124, $0.1 \mathrm{mg}$ sensitivity), a sonicator (SONICA, Spincotech Pvt Ltd.) were used in this study.

\section{Chromatographic conditions}

The optimal composition of the mobile phase was found to be acetonitrile: water (60:40V/V). The flow rate was set to $1 \mathrm{~mL} / \mathrm{min}$ and UV detection was carried out at $256 \mathrm{~nm}$. The mobile phase was filtered through a $0.45 \mu \mathrm{m}$ membrane filter and was sonicated before use.

\section{Preparation of standard drug solution and calibration curve}

Drug stock solution was prepared by dissolving $10 \mathrm{mg}$ of accurately weighed quantity into $100 \mathrm{~mL}$ volumetric flask containing $50 \mathrm{~mL}$ of acetonitrile. After the complete dissolution, the volume was made up to the mark with acetonitrile. The standard stock solution was observed to contain $100 \mu \mathrm{g} / \mathrm{mL}$. Suitable volume from this solution was further diluted to get appropriate concentration levels according to the requirement. From the above stock solution, dilutions were made in the concentration range of $10-50 \mu \mathrm{g} / \mathrm{mL}$. A volume of $20 \mu \mathrm{L}$ 
of each sample was injected into the column. A graph was plotted as concentration of drug versus peak area response. It was found to be linear for the given concentration of the drug (Figure 2, 3 and Table 1).

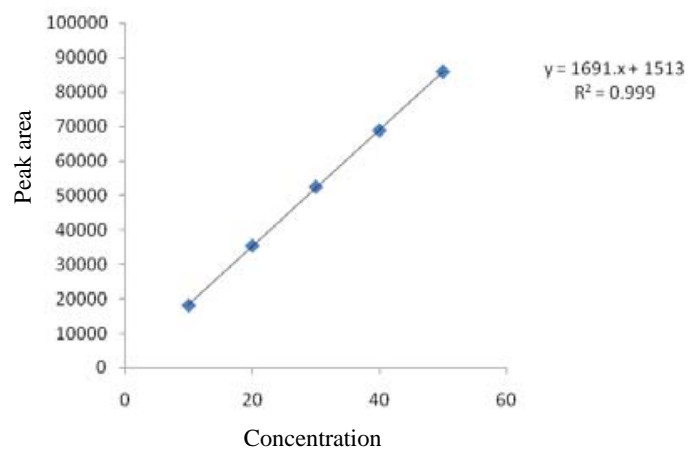

Figure 2. Linearity graph

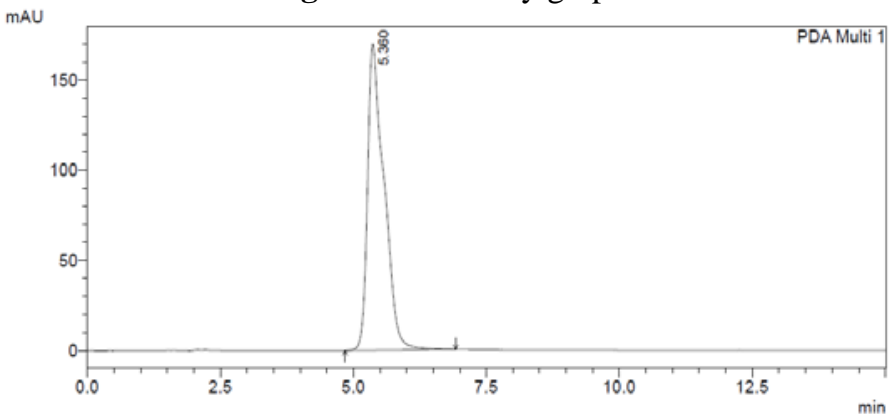

Figure 3. Chromatogram for standard

Preparation of sample solution from pharmaceutical dosage form

Twenty tablets (VFEND) of Voriconazole were accurately weighed, averaged and finally powdered. A quantity of powder equivalent to $100 \mathrm{mg}$ was weighed and transferred to a $100 \mathrm{~mL}$ volumetric flask containing $50 \mathrm{~mL}$ of Acetonitrile. The mixture was sonicated for $0.5 \mathrm{~h}$ to ensure complete solubility of the drug and filtered through $0.45 \mu \mathrm{m}$ membrane filter and made up to the volume with acetonitrile. From the resultant solution $5 \mathrm{~mL}$ was taken in a $100 \mathrm{~mL}$ volumetric flask and made up to the volume with acetonitrile to the final concentration of $50 \mu \mathrm{g} / \mathrm{mL}$ (Figure 4 and Table 2).

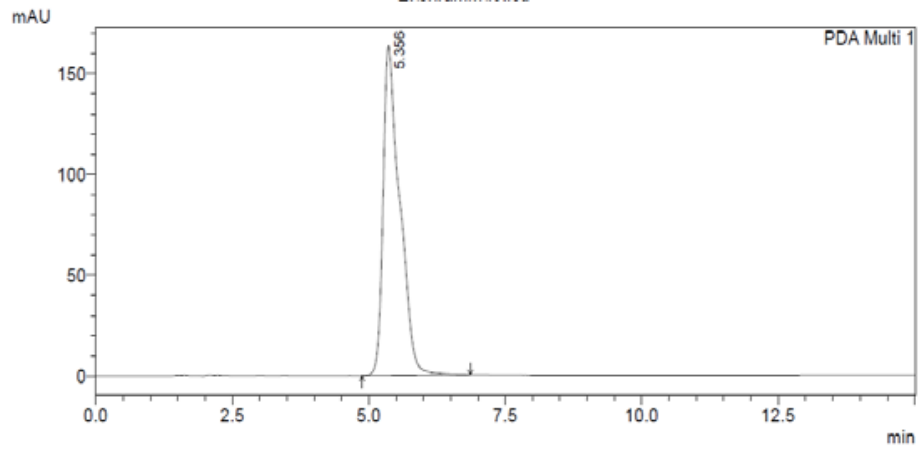

Figure 4. Chromatogram for sample 
Table 1. Validation and system suitability study

\begin{tabular}{ccc}
\hline S.No & Parameter & Value \\
\hline 1. & Retention time & $5.360 \mathrm{~min}$ \\
2. & Theoretical plates & 10596 \\
3. & Tailing factor & 1.689 \\
4. & LOD, $\mu \mathrm{g} / \mathrm{mL}$ & 0.749 \\
5. & LOQ, $\mu \mathrm{g} / \mathrm{mL}$ & 2.24 \\
6. & Linearity range, $\mu \mathrm{g} / \mathrm{mL}$ & $10-50$ \\
& Slope & 1691 \\
& Intercept & 1513 \\
& Correlation coefficient & 0.999 \\
\hline
\end{tabular}

Table 2. Analysis of formulation

\begin{tabular}{ccccc}
\hline S.No & Formulation & Labelled amount & Amount recovered in $\mathrm{mg}$ & \%RSD \\
\hline 1 & VFEND & $50 \mathrm{mg}$ & 49.6224 & \pm 0.560 \\
\hline \multicolumn{5}{c}{${ }^{*}$ Each value is average of three determinations }
\end{tabular}

\section{Method validation}

System suitability study

System suitability is an integral part of the method development and is used to ensure adequate performance of chromatographic system. Retention time (min), Theoretical plate count, Tailing Factor, Linearity $(\mu \mathrm{g} / \mathrm{mL})$, Detection of limit $(\mu \mathrm{g} / \mathrm{mL})$, Quantification limit $(\mu \mathrm{g} / \mathrm{mL})$ were evaluated for five replicate injections of the drug at a concentration of $50 \mu \mathrm{g} / \mathrm{mL}$ (Table 1).

\section{Precision}

Intraday and inter day precision study of voriconazole was carried out by estimating the corresponding response 5 times on the same day and on 5 different days for the concentration of $50 \mu \mathrm{g} / \mathrm{mL}$. The \% RSD obtained under different conditions were found to be less than $2.0 \%$ (Table 3 ).

Table 3. Precision study

\begin{tabular}{cccc}
\hline S.No & Concentration & $\begin{array}{c}\text { Intraday precision } \\
\text { (peak area) }\end{array}$ & $\begin{array}{c}\text { Interday precision } \\
\text { (peak area) }\end{array}$ \\
\hline 1 & 50 & 86019 & 86128 \\
2 & 50 & 86087 & 87012 \\
3 & 50 & 86120 & 86101 \\
4 & 50 & 85998 & 86112 \\
5 & 50 & 86348 & 85213 \\
Mean & & 86114.4 & 86113.2 \\
Standard deviation & & 139.64 & 636.11 \\
\%R.S.D & & 0.16216 & 0.7386 \\
\hline
\end{tabular}

\section{Accuracy}

To determine the accuracy of the proposed method, recovery studies were carried out in triplicate by spiking different concentrations of bulk drug with pre-analyzed formulation with three different concentrations of standard containing $80 \%, 100 \%$ and $120 \%$ of the pure drug. The percentage recovery obtained was $99.89-100.86 \%$ for the assay (Table 4). 
Table 4. Accuracy

\begin{tabular}{|c|c|c|c|c|}
\hline Level \% & \multicolumn{2}{|c|}{ Concentration, $\mu \mathrm{g} / \mathrm{mL}$} & $\begin{array}{c}\text { \%Recovery of } \\
\text { pure drug }\end{array}$ & $\begin{array}{c}\text { Mean \% recovery } \\
\text { of pure drug }\end{array}$ \\
\hline & Pure drug & Formulation & & \\
\hline 80 & 32 & 40 & 100.23 & 100.23 \\
\hline 100 & 40 & 40 & 99.89 & 99.89 \\
\hline 120 & 48 & 40 & 100.86 & 100.86 \\
\hline
\end{tabular}

*Each value is average of three determinations

\section{Sensitivity}

The sensitivity of measurement of voriconazole by the use of proposed method was estimated in terms of limit of detection and limit of quantification.

\section{Limit of detection}

Limit of detection can be calculated using the following equation according to ICH guidelines.

$$
\mathrm{LOD}=3.3(\mathrm{SD}) / \mathrm{S}
$$

Where $\mathrm{SD}=$ standard deviation of response (peak area) and $\mathrm{S}=$ Slope of the calibration curve (Table 1).

\section{Limit of quantification}

Limit of quantification can be calculated using the following equation according to ICH guidelines.

$$
\mathrm{LOQ}=10(\mathrm{SD}) / \mathrm{S}
$$

Where $\mathrm{SD}=$ standard deviation of response (peak area) and $\mathrm{S}=$ Slope of the calibration curve (Table 1).

\section{Robustness}

The robustness of the method was determined to assess the effect of small but deliberate variation of chromatographic conditions on estimation of voriconazole. Robustness was determined by changing the mobile phase flow rate from $1 \mathrm{~mL} / \mathrm{min}$ to $1.1 \mathrm{~mL} / \mathrm{min}$ and composition of mobile phase from 60:40 to 62:38 of acetonitrile: water composition. There was no significant change in the peak area and tailing factor of voriconazole (Figure 5, 6 and Table 5).

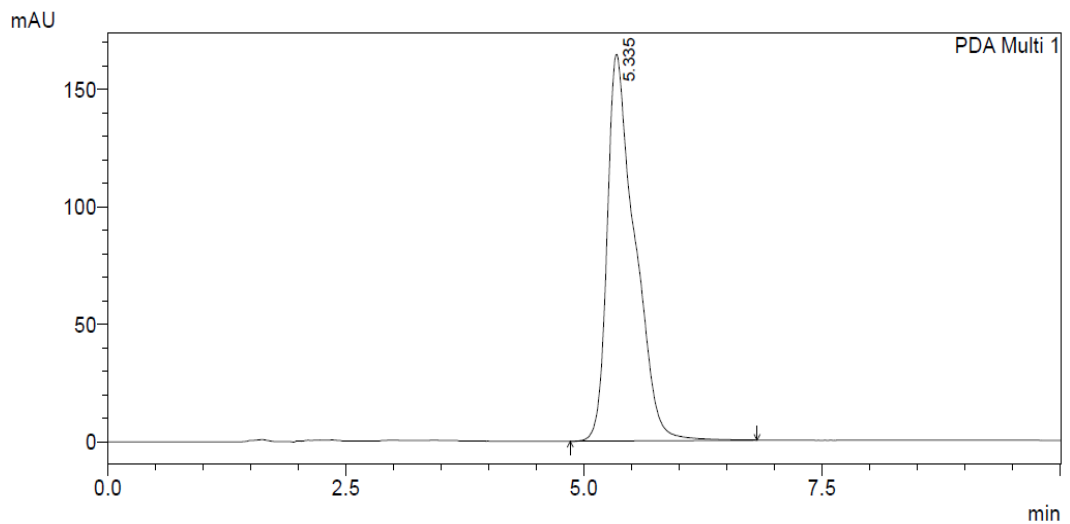

Figure 5. Chromatogram for robustness (change in mobile phase composition) 


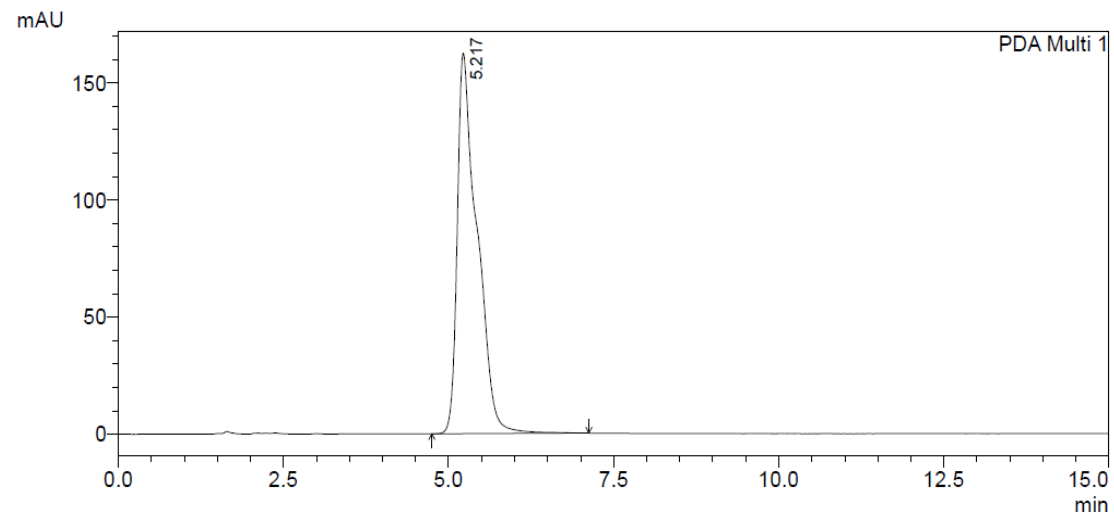

Figure 6. Chromatogram for robustness (change in flow rate)

Table 5. Robustness study

\begin{tabular}{|c|c|c|c|c|c|}
\hline Parameter & $\begin{array}{c}\text { Peak } \\
\text { area }\end{array}$ & Mean & $\begin{array}{l}\text { Standard } \\
\text { deviation }\end{array}$ & $\%$ RSD & $\begin{array}{l}\text { Tailing } \\
\text { factor }\end{array}$ \\
\hline \multicolumn{6}{|l|}{ Flow rate } \\
\hline \multirow[t]{2}{*}{$1.1 \mathrm{ml} / \mathrm{min}$} & 86356 & \multirow[b]{2}{*}{86422} & \multirow[b]{2}{*}{110.01} & \multirow[b]{2}{*}{0.127} & 1.612 \\
\hline & $\begin{array}{l}86361 \\
86549\end{array}$ & & & & $\begin{array}{l}1.597 \\
1.584\end{array}$ \\
\hline \multicolumn{6}{|l|}{$\begin{array}{c}\text { Mobilephase } \\
\text { composition(acetonitrile:water) }\end{array}$} \\
\hline \multirow[t]{2}{*}{$62: 38$} & 86419 & \multirow[b]{2}{*}{86268.67} & & & 1.679 \\
\hline & $\begin{array}{l}86389 \\
85998\end{array}$ & & 234.88 & 0.272 & $\begin{array}{l}1.710 \\
1.612\end{array}$ \\
\hline
\end{tabular}

\section{Results and Discussion}

Chromatographic parameters were optimized to develop a HPLC method for the estimation of voriconazole with different mobile phases Methanol: Water, Acetonitrile: Water, Acetonitrile: Buffer, Methanol: Buffer were used in different compositions of mobile phases (80:20, 60:40, $55: 45,90: 10)$ at different flow rates $(0.5,1,1.2,1.5,1.8 \mathrm{~mL} / \mathrm{min})$. Then the composition of the mobile phase acetonitrile and water in the ratio of 60:40 at flow rate of $1 \mathrm{~mL} / \mathrm{min}$ gave sharp peak with minimum tailing for voriconazole. The effluent was monitored at $256 \mathrm{~nm}$. The retention time of the drug was 3.560 minutes. The linearity was obtained in the concentration range of $10-50 \mu \mathrm{g} / \mathrm{mL}$. LOD and LOQ were determined from the slope and standard deviation of $Y$-intercept of the regression line of the calibration curve. They were found to be 0.749 and $2.24 \mu \mathrm{g} / \mathrm{mL}$, respectively. The precision was found that the \%RS is less than $2 \%$, which indicates that the proposed method has good reproducibility. From the results shown in the accuracy it was found that the percentage recovery values of pure drug from the pre-analyzed solutions of formulation were between $99.89-100.86 \%$, which indicates that the method was accurate and also reveals that the commonly used excipients and additives present in the pharmaceutical formulation were not interfering in the analysis of proposed method. There was no considerable change in the peak areas and tailing factor with the change in the flow rate, composition of the mobile phase, indicates that the developed method was found to be robust. The system suitability parameters also reveal that the values were within the specified limits for the proposed method. 


\section{Conclusion}

The proposed method was found to be simple, precise, accurate and robust for the estimation of voriconazole in pure and its pharmaceutical dosage form was developed and validated. The method has been found best than from few methods reported because of the use of economical and readily available mobile phase. The method would be extensively used for analysis of voriconazole in bulk and its dosage forms.

\section{Acknowledgement}

Authors are thankful to Raghu College of Pharmacy for providing necessary facilities to carry out this work.

\section{References}

1. Tripathi K D, Essentials of Medical Pharmacology, New Delhi, Jaypee Brothers, $6^{\text {th }}$ Edn., 2008, 765.

2. John H Block and John M Beale Jr, Wilson and Griswold's. Textbook of Organic Medicinal and Pharmaceutical Chemistry, $11^{\text {th }}$ Ed., Lippincott Williams \& Wilkins, Philadelphia PA. 2004, 244-245.

3. Verweij-vanWissen C P W G M, Burger D M, Verweij P E, Aarnoutse R E and Bruggemann R J M, J Chromatogr B, 2012, 887-888, 79-84;

DOI:10.1016/j.jchromb.2012.01.015

4. Pehourcq F, Jarry C and Bannwarth B, Biomedical Chromatogr., 2004, 18(9), 719722; DOI:10.1002/bmc.383

5. Lei Zhou, Randolph D Glickmann, Nancy Chen, William E Sponsel, John R Graybill and Kwok-Wai Lam, J Chromatogr B, 2002, 776(2), 213-220; DOI:10.1016/S1570-0232(02)00344-6

6. Franziska Simmel, Jens Soukup, Alexander Zoerner, Joachim Radke and Charlotte Kloft, Anal Bio Anal Chem., 2008, 392, 479-488.

7. Manali W Jain, Atul A Shirkhedkar and Sanjay J Surana, Arabian J Chem., DOI: 10.1016/j.arabjc.2012.09.006

8. Khetre A B, Sinha P K, Mrinalini C Damle and Mehendre R, Indian J Pharm Sci., 2009, 71(5), 509-514; DOI:10.4103/0250-474X.58178

9. Nagarjuna A, Padmaja K Reddy K, Mukkanti M V and Suryanarayana A, Chromatographia, 2007, 66(5-6), 439-441; DOI:10.1365/s10337-007-0315-6

10. Shan Cheng, Fenq Qiu, Jia Huang and Junge He, J Chromatogr Sci., 2007, 45(7), 409-414; DOI:10.1093/chromsci/45.7.409 